\title{
Marzena Dyjakowska
}

The John Paul II Catholic University of Lublin, Poland ORCID: 0000-0001-5040-6058

marzena.dyjakowska@kul.pl

\section{The Evidence Given by Slaves in the Trials of crimen maiestatis}

\author{
Dowód z zeznań niewolników w procesach \\ o crimen maiestatis
}

\begin{abstract}
According to the rule being in force in Republican Rome, the slave testimony could not be used to the detriment of their owners, in particular in cases punishable by death (in caput domini), and the slaves could not bring charges against the owners. The few crimes in which exceptions were permitted was the crime of majesty. This article presents the most important views of Roman authors on the credibility of testimony given under torture and also explains the reasons for using torture in interrogating slaves. During the Principate period, the ban on interrogating slaves against their owners in maiestas cases was circumvented and then was abolished by imperial constitutions. During the Dominate period, the crime of lese-majesty was the only one in which a slave was allowed to accuse his master.
\end{abstract}

Keywords: interrogation; the Principate period; the Dominate period; slaves; crime of lese-majesty

CORRESPONDENCE ADDRESS: Marzena Dyjakowska, PhD, dr. habil., Associate Professor, The John Paul II Catholic University of Lublin, Faculty of Law, Canon Law and Administration, al. Racławickie 14, 20-950 Lublin, Poland. 


\section{INTRODUCTION}

This study discusses the issue of testimony given by slaves during trials in cases of the crime of lese-majesty which was one of the most grave offences against the state in ancient Rome. In particular, attention was paid to the testimony against the owners, since they raised the most doubts from the legal point of view. The concept of testimony covers both the testimony made by slaves as witnesses and in the form of accusation or even report of a crime.

\section{EVIDENTIARY VALUE OF SLAVE TESTIMONIES}

Witness statements (testimonia) were definitely the most important evidence in the Roman criminal trial and, as a rule, all those who did not fall under any prohibitions could testify. ${ }^{1}$ Testimonies made by slaves were also used, although they were never referred to as testes, ${ }^{2}$ and most sources refer to their interrogation not as interrogatio as in the case of free men, but quaestio. ${ }^{3}$ The slaves were interrogated with the mandatory use of torture to increase the credibility of the testimony: the lowest social status made slaves exposed not only to being attributed a greater propensity to commit crimes, ${ }^{4}$ but also - as it can be assumed - to questioning their honesty in testifying. At the same time, both literary and legal sources contain many statements demonstrating that their authors doubt the veracity of testimonies given under the influence of pain and fear. These were the factors pointed out by Cicero in his speech to defend Publius Cornelius Sulla:

Cic. Sull. 78: Quaestiones nobis servorum accusator et tormenta minitatur. In quibus quamquam nihil periculi suspicamur, tamen illa tormenta gubernat dolor, moderatur natura cuiusque cum animi tum corporis, regit quaesitor, flectit libido, corrumpit spes, infirmat metus, ut in tot rerum angustiis nihil veritati loci relinquatur.

A similar argument appeared in De partitions oratoria, where Cicero also questioned the credibility of words spoken under torture - for some interrogatees prefer to lie rather than endure pain, while others, physically more resilient, will not reveal the truth either:

1 W. Litewski, Rzymski proces karny, Kraków 2003, p. 94.

2 Ibidem.

3 U. Vincenti (,,Duo genera sunt testium”. Contributo allo studio della prova testimoniale nel processo romano, Padova 1989, p. 85) points out that in most legal sources, the term quaestio means an interrogation with the use of torture (which is manifested by the additional expression per tormenta used in some cases). This term is used in a broader meaning, as interrogation in general, in the definition presented by Ulpian in D. 29.5.1.25.

4 O. Robinson, Slaves and the Criminal Law, “ZSS” 1981, vol. 98(1), p. 227. 
Cic. Part. orat. 14.50: Saepe etiam quaestionibus resistendum est, quod et dolorem fugientes multi in tormentis ementiti persaepe sint morique maluerint falsum fatendo quam infitiando dolere; multi etiam suam vitam neglexerint ut eos qui eis cariores quam ipsi sibi essent liberarent, alii autem aut natura corporis aut consuetudine dolendi aut metu supplicii ac mortis vim tormentorum pertulerint, alii ementiti sint in eos quos oderant. ${ }^{5}$

The above arguments are not dissimilar to those voiced much later, during the reign of the Severan dynasty, in the eighth book of De officio proconsulis by Ulpian, who also advised caution in the evaluation of testimony made under torture, which do not always make it possible to achieve the primary objective of interrogation, i.e. to discover the truth:

Ulp. D. 48.18.1.23: Quaestioni fidem non semper nec tamen numquam habendam constitutionibus declaratur: etenim res est fragilis et periculosa et quae veritatem fallat. nam plerique patientia sive duritia tormentorum ita tormenta contemnunt, ut exprimi eis veritas nullo modo possit: alii tanta sunt impatientia, ut quodvis mentiri quam pati tormenta velint: ita fit, ut etiam vario modo fateantur, ut non tantum se, verum etiam alios criminentur.

Ulpian, probably aware of the increasingly frequent practice of torture in criminal trials, cited a number of imperial rescripts setting additional requirements for this means of obtaining testimony:

Ulp. D. 48.18.1.pr.-1: In criminibus eruendis quaestio adhiberi solet. sed quando vel quatenus id faciendum sit, videamus. et non esse a tormentis incipiendum et divus augustus constituit neque adeo fidem quaestioni adhibendam, sed et epistula divi hadriani ad sennium sabinum continetur. 1. Verba rescripti ita se habent: <ad tormenta servorum ita demum veniri oportet, cum suspectus est reus et aliis argumentis ita probationi admovetur, ut sola confessio servorum deesse videatur>.

On the other hand, Paulus referred to the following edict of Augustus:

Paul. D. 48.18 .8 pr.: Edictum divi Augusti, quod proposuit Vibio Habito et Lucio Aproniano consulibus, in hunc modum extat: Quaestiones neque semper in omni causa et persona desiderari debere arbitror, et, cum capitalia et atrociora maleficia non aliter explorari et investigari possunt quam per servorum quaestiones, efficacissimas eas esse ad requirendam veritatem existimo et habendas censeo.

5 A distrust towards torture as a method of taking evidence had been expressed by Aristotle (Rhet. 1377a). For more details, see A. Triggiano, Evidence Given under Torture in Aristotle and Cicero, “Teoria e Storia del Diritto Privato” 2009, no. 2, pp. 5-6; B. Sitek, ,, Questionem” intellegere debemus tormenta et corporis dolorem ad eruendam veritatem, [in:] Crimina et mores. Prawo karne i obyczaje w starożytnym Rzymie, ed. M. Kuryłowicz, Lublin 2001. 


\section{ADMISSIBILITY OF TESTIMONIES MADE BY SLAVES TO THE DETRIMENT OF THEIR OWNERS}

It follows from the rescripts cited above that the proceeding should not be started with inflicting unnecessary pain, and that interrogation of slaves using torture should be applied only when the other evidence has made the guilt of the suspect sufficiently plausible that it can only be ultimately confirmed by the testimony of the slaves. ${ }^{6}$ Such testimony was only supposed to supplement other incriminating evidence; it could not be considered the sole evidence of guilt of the accused. It was all the more inadmissible to base the consideration of the case on the testimony of only one slave, excluding other evidence. This can be seen in view of the rescript of Emperors Marcus Aurelius and Lucius Verus to Cornelius Proculus, mentioned by Ulpian in the work already referred to herein:

Ulp. D. 48.18.1.4: Idem cornelio proculo rescripserunt non utique in servi unius quaestione fidem rei constituendam, sed argumentis causam examinandam.

Despite numerous objections, this method of taking evidence was apparently considered useful, since Cicero, in another passage of De partitione oratoria, suggesting again that one be cautious in evaluating the words spoken by the tortured, admits that if this method were to be considered useless, it would probably have been abolished by the ancestors. He considers both the prohibition of torturing free citizens and interrogating slaves to the detriment of their owners a sign of the wisdom of the Romans, unlike the Athenians and Rhodians:

Cic. Part. orat. 34.117-118: Sin quaestiones habitae aut postulatio ut habeantur causam adiuvabunt, confirmandum genus primum quaestionum erit, dicendum de vi doloris, de opinione maiorum, qui eam rem totam nisi probassent certe repudiassent; de institutis Atheniensium, Rhodiorum, doctissimorum hominum, apud quos etiam (id quod acerbissimum est) liberi civesque torquentur; de nostrorum etiam prudentissimorum hominum institutis, qui cum de servis in dominos quaeri noluissent, de incestu tamen, et coniuratione quae facta me consule est, quaerendum putaverunt. ${ }^{7}$

6 For example, see A. Chmiel, Ochrona bezpieczeństwa właścicieli niewolników w świetle S.C. Silanianum -zagadnienia dowodowe, [in:] Ochrona bezpieczeństwa i porzadku publicznego w prawie rzymskim, eds. K. Amielańczyk, A. Dębiński, D. Słapek, Lublin 2010, pp. 60-61. E. Loska (Kilka uwag na temat zeznań niewolników w procesie karnym, „Zeszyty Naukowe KUL” 2017, no. 3, p. 456) points out that the continuation of this policy can also be seen in post-classical law: the Emperors Constantine and Constans considered torture an abhorrent practice to be only used as a last resort, including slaves (C.Th. 12.1.39).

7 Cf. Cicero, Pro Rabirio perduellionis reo 3.10: Sed ista laus primum est maiorum nostrorum, Quirites, qui expulsis regibus nullum in libero populo vestigium crudelitatis regiae retinuerunt, deinde multorum virorum fortium qui vestram libertatem non acerbitate suppliciorum infestam sed lenitate legum munitam esse voluerunt. The widespread opinion on the ban on torturing free citizens in the period of the Republic is questioned by C. Russo-Ruggeri (Quaestiones ex libero homine. La 
Cicero attributed the observance of the above rule to the wisdom of ancestors who considered a testimony obtained in such a contemptible way even sadder than the death of the owner:

Cic. Mil. 22.59: Sed tamen maiores nostri in dominum quaeri noluerunt, non quin posset verum inveniri, sed quia videbatur indignum esse et domini morte ipsa tristius.

While noting the prohibition of torture of slaves testifying against their owners in cases punishable by death - in caput domini - in force during the Republic, Cicero also pointed to exceptions. Such testimonies could be used in trials for incest (incestum) and for conspiracy (coniuratio). In the passage cited above, the author undoubtedly referred to the events of 63 B.C., inspired by Lucius Sergius Catilina, who intended to seize power through a coup d'état. Cicero, a consul at the time, thwarted the conspiracy by exposing it to the Senate. Interrogating slaves in caput domini was permissible in the case of the crime of lese-majesty, one of the forms of which was coniuratio. The term coniuratio must be understood as a criminal offence against the State-coniuratio in rem publicam facta, although, as noted by L. Schumacher, Roman criminal law does not know that offence as such: there were neither leges governing that act nor special courts (quaestiones de coniuratione) ${ }^{8}$ However, given that the criteria of the offence of maiestas were not strictly defined, it can be believed that the actions attributed to Catilina, such as conspiracy, treason or attempted political coup met these criteria. ${ }^{9}$ According to Catullus' testimony, the Senate proposed prizes not only for freemen, but also for slaves (freedom and one hundred thousand sestertii). ${ }^{10}$ Eventually, the basis for the indictment brought by Lucius Emilius Paulus under lex Plautia de vi was the use of violence (vis publica). ${ }^{11}$ Such classification can be explained by the fact that the accusation was preceded by the senatus consultum ultimum of 21 October 63 B.C., since in this situation any acts of violence would have to be considered as posing a threat to the State security. ${ }^{12}$ Cicero referred to these events in the above-mentioned speech in defence of Lucius Cornelius Sulla,

tortura degli uomini liberi nella repressione criminale romana dell'eta repubblicana e del I secolo dell'imperio, Milano 2002, p. 95). According to this author, this is to be confirmed by fragments by Cicero himself in the speeches against Verres and the Philippicae.

${ }^{8}$ L. Schumacher, Servus index: Sklavenverhör und Sklavenanzeige im republikanischen und kaiserzeitlichen Rom, Wiesbaden 1982, p. 61.

${ }^{9}$ It is confirmed by the reconstruction of the lex Appuleia de maiestate minuta of ca. 103 B.C. made by R. Bauman (The Crimen Maiestatis in the Roman Republic and Augustan Principate, Johannesburg 1970, p. 54): ...qui homines ad seditionem vel vim concitavit concitaveritve vel tr. Pl. Intercedenti non paruit, quo maiestas populi Romani minueretur.

${ }_{10}$ Sallustius, Cat. 30.6: ... si quis indicavisset de coniuratione, quae contra rem publicam facta errat, praemium servo libertatem et sestertia centum, libero inpunitatem eius rei et sestertia ducenta.

11 Sallustius, Cat. 31.4.

${ }^{12}$ L. Schumacher, op. cit., p. 65. 
accused of being involved in Catilina's conspiracy, and his doubts over the credibility of the testimony of slaves given under torture, requested by the accuser Lucius Manlius Torquatus, may have been motivated, as L. Schumacher supposes, by the fear that they might prove unfavourable to the accused..$^{13}$ The author pointed out that both Cicero and other authors, i.a. Aristotle and Quintilian, did not generally deplore such questioning, but only stipulated not to draw erroneous conclusions from the questioning and not to believe unrestrictedly in everything said.

\section{THE MANNER OF INTERROGATION OF SLAVES}

In the trials before quaestiones, slaves were not interrogated by the entire court, but by the so-called quaesitor. Unfortunately, the historical sources do not allow us to determine precisely who performed this role in the proceedings before iudicium publicum, but it can be assumed that the president of the tribunal did not. The duty of the quaesitor was certainly to decide on the type of torture and the way it was carried out, and most likely he also had the right to ask questions to the slave who was being questioned, the latter right being also vested in the parties. Based on such an interrogation, a report called tabella used to be drawn up, read out and stamped by those present during the quaestio, and then forwarded to the court. The slave interrogation reports contained a very detailed description of the course of the hearing, probably by citing literally each question the slave was asked during the quaestio, and each answer given. Moreover, it used to be noted whether the slave told the truth immediately, whether he had done so during torture and withdrew or maintained previous testimony. ${ }^{14}$

It is worth mentioning that due to the gravity of this crime, the proceedings also had other special features, which constituted exceptions to the rules of Roman criminal procedure. These included the possibility of prosecution by persons who cannot act as prosecutors in other cases, and who during the Republic were only allowed to submit informal reports. These persons included slaves when their owners were concerned (as well as freedmen in relation to their patrons), ${ }^{15}$ as will be discussed further herein. At present, attention will be paid to the testimony of slaves questioned as witnesses in the cases of their owners accused of maiestas.

13 Ibidem, p. 68.

14 For example, see A. Chmiel, Immediacy Principle in Roman Criminal Procedure, „Krytyka Prawa" 2016, vol. 8(2), pp. 8-9; idem, Zasada kontradyktoryjności w rzymskim procesie karnym, „Zeszyty Naukowe Uniwersytetu Rzeszowskiego. Seria Prawnicza. Prawo” 2018, no. 101, p. 47.

15 Other peculiarities of the crimen maiestatis proceedings are discussed in more detail in M. Dyjakowska, Crimen laesae maiestatis. Studium nad wplywami prawa rzymskiego w dawnej Polsce, Lublin 2010, pp. 73-75. 
The possibility of using the testimony of slaves testifying in caput domini in such cases seems to contradict two of Tacitus' passages in Annales. One of them concerns the trial of Libo Drusus, accused in A.D. 16 of an attempted coup d'état (moliri res novas - Tacitus, Annales 2.27). The proceedings were conducted before the Senate under an extraordinary procedure (cognitio extra ordinem). As the accused did not plead guilty, the Senate decided to question his slaves. In order not to violate the old Senate resolution, not specified by Tacitus in more detail, which prohibited the interrogation of slaves to the detriment of the owner, Tiberius ordered them to be transferred to the Treasury agent, which, as Tacitus notes, was an unprecedented solution:

Tac. Ann. 2.30: ...negante reo adgnoscentis servos per tormenta interrogari placuit. et quia vetere senatus consulto quaestio in caput domini prohibebatur, callidus et novi iuris repertor Tiberius mancipari singulos actori publico iubet, scilicet ut in Libonem ex servis salvo senatus consulto quaereretur.

The same trick was used a few years later (A.D. 22) in the trial of Gaius Junius Silanus, proconsul of Asia, accused of extortion and additionally of crimen maiestatis:

Tac. Ann. 3.67: ...servos quoque Silani ut tormentis interrogarentur actor publicus mancipio acceperat.

For both of these passages, it is intriguing that slave owners were taken away by the State from their owners in the event of the accusation of crimen maiestatis, where, according to the earlier Cicero's statement, there was a possibility of questioning slaves to the detriment of the owner. E. Loska, when questioning the credibility of Tacitus' statement, argues that it contains information not confirmed by any other source. However, it is worth asking whether lese-majesty was the basic charge faced by both defendants, or even was it a formal charge in both cases?

\section{ACTS QUALIFIED AS CRIMEN MAIESTATIS}

When studying the political processes of the period of Tiberius' rule, it is easy to notice that this ruler continued the practice initiated by his predecessor Augustus to bend the crimen maiestatis laws by constantly widening the catalogue of acts considered lese-majesty. Moreover, cases of maiestas were referred to the imperial court or, as in both of the above cases, to the Senate court, which, on the one hand, allowed the procedure of quaestiones ${ }^{16}$ to be waived and the perpetrators to be

${ }^{16}$ The quaestio maiestatis was established under lex Appuleia de maiestate minuta (see A.W. Zumpt, Das Criminalrecht der römischen Republik, vol. 2, part 1, Aalen 1993, p. 228 ff.; R.A. Bauman, 
punished with discretionary penalties, and, on the other hand, certain legal tricks were used to ensure that acts previously unqualified as crimen maiestatis were tried by quaestio maiestatis under the laws on maiestas. ${ }^{17}$ The Tacitus' statement about the growing role of legislation in these matters (Adolescebat interea lex maiestatis - Annales 2.50) can be referred to this practice. Although the catalogue of acts treated as lese-majesty used to be continuously expanded, it is uncertain whether in all the political trials mentioned by Tacitus and Suetonius the crimen maiestatis was a formal basis for the prosecution. While in the case of Gaius Junius Silanus, Tacitus clearly mentions this crime as one of the charges (although Tacitus suggests that the charge was made for purely procedural reasons: to prevent the defendant's relatives from helping him - Annales 3.67) ${ }^{18}$ in describing the Libo's trial, he focuses on describing the acts the accused is charged with (without indicating their legal qualification) which involved asking fortune tellers about his future career, which could be interpreted as a sign of plans to seize the imperial power. Tacitus himself assessed the accusations presented by the accuser as stupid and irrelevant (Annales 2:30), which could only prove Libo's guilt when interpreted with a great bias against him. ${ }^{19}$ However, Tacitus' comments do not show that the basic charge faced by both Libo and Silanus was the crime of lese-majesty (and in the case of Silanus, the author explicitly stated that the charge of crimen maiestatis appeared due to procedural reasons ${ }^{20}$ ), which is why Tiberius could try to show that he

op. cit., p. 69). Some authors attribute the authorship of this opinion to Sulla (see Th. Mommsen, Röömisches Strafrecht, Graz 1955, p. 203; P.M. Schisas, Offences Against the State in Roman Law and the Courts Which Were Competent to Take Cognisance of Them, London 1926, p. 121; A. Pesch, De perduellione, crimine maiestatis et memoria damnata, Aachen 1995, p. 195). See also M. Dyjakowska, Ochrona bezpieczeństwa i porządku publicznego a rzymskie ustawy o obrazie majestatu, [in:] Ochrona bezpieczeństwa i porządku publicznego ..., pp. 68-69.

${ }_{17}^{17}$ For more details, see M. Dyjakowska, Crimen laesae maiestatis..., pp. 39-40.

18 The fact that in the Silanus' case the charge of maiestas was of a secondary nature shows, according to R.S. Rogers (Criminal Trials and Criminal Legislation under Tiberius, Middletown 1935, pp. 67-68), that this charge, as presented by Tacitus, was neither put forward during the trial nor constituted the basis for the conviction. That would justify depriving Silanus of his slaves so that they can testify in his case. Rogers also doubts the objectivity of Tacitus' words about the reason for adding the charge of crimen maiestatis, attributing them to the historian's resentment towards the emperor.

${ }_{19}$ For example, the question asked by Libo to the fortune tellers whether he would ever be so rich as to pave the Via Appia to Brundisium with money could be treated as a hidden question "will I be the emperor?", because such funds were available only to the emperor (see W. Seibt, Die Majestätsprozesse vor dem Senatsgericht unter Tiberius, Wien 1969, p. 30). It should be pointed out that Libo's questions to the fortune tellers concerned Libo himself, not the emperor or members of his family, which was considered a form of crimen maiestatis. For more details, see R. MacMullen, Enemies of the Roman Order: Treason, Unrest, and Alienation in the Empire, Cambridge 1966, p. $130 \mathrm{ff}$.

${ }^{20}$ Tacitus, when discussing the trial of Caesius Cordus in A.D. 21, made a symptomatic observation that the charge of crimen maiestatis was regularly attached to charges of other crimes (omnium accusationum complementum erat-Annales 3.38), probably with the intention to increase the probability of conviction. 
respected the old principle of not using slave testimonies against the owner. It is worth noting that according to Dio Cassius (Historia Romana 55.5.4) the trick of taking the slaves away from the owner and selling them to the Treasury agent or to the emperor himself so that he can then question them, was to be first used by Augustus in A.D. 8. The fact that the trick described by Dio related to the trials of crimen maiestatis may be supported by a mention about plots against Augustus and officials placed just after this sentence. ${ }^{21}$ Although Dio Cassius did not explicitly mention the rewards for reports submitted by slaves, such rewards were mentioned in the Ulpian's $56^{\text {th }}$ Book ad edictum in the context of discussions between jurists on the lex Cornelia de iniuriis. ${ }^{22}$ Moreover, another passage from Dio (Historia Romana 57.19) shows that under Tiberius' rule, as far as lese-majesty was concerned, not only slaves testifying against their owners, but even free citizens used to be tortured. Thus, contrary to the statutory prohibitions (probably included in the lex Iulia de vi publica from approx. 19-16 B.C.) providing for a penalty for a judge who tortured a citizen without respecting his right to provocatio, in maiestas trials even Roman citizens usually not subject to torture could not feel safe, ${ }^{23}$ it is all the less surprising that the practice of torture in the cases of such slaves in caput domini perpetuated over time already during the reign of Tiberius, according to the Dio's account referred to above. A confirmation of this practice can be found in the fragment of Marcianus' comment on the lex Iulia maiestatis, quoted in the Code of Justinian:

C. 9.8.6.1: In hoc item crimine, quod ad laesam maiestatem imperatoris pertinet, etiam in caput domini servos torqueri. Marcianus libro primo de publicis iudiciis titulo ad legem iuliam maiestatis.

The location of Marcianus' statement does not show that the permit to torture slaves to obtain testimony against their owners was already provided for in the lex Iulia de maiestate, probably dating back to the time of Caesar, not Augustus. ${ }^{24}$ It should be borne in mind that the statements on that law, made by jurists mostly in D. 48.4, are merely a commentary and do not prove that the particular solutions were actually contained in the original text of the law.

${ }^{21}$ R.A. Brunt, Evidence given under Torture in the Principate, "ZSS" 1980, vol. 97(1), p. 257. See also L. Solidoro Maruotti, La disciplina del crimen maiestatis tra tardo antico e medioevo, [in:] Diritto e giustizia nel processo. Prospettive storiche constituzionali e comparatistiche, eds. C. Cascione, C. Masi Doria, Napoli 2002, p. 397.

${ }^{22}$ Ulp. D. 47.10.5.11: Et ei, qui indicasset, sive liber sive servus sit, pro modo substantiae accusatae personae aestimatione iudicis praemium constituitur, servo forsitan et libertate praestanda. See also L. Schumacher, op. cit., p. 122.

${ }^{23}$ Pauli Sententiae 5.29.2: In reum maiestatis inquiri prius convenit, quibus opibus, qua factione, quibus hoc auctoribus feceri ... et ideo, cum de eo quaeritur, nulla dignitas a tormentis excipitur.

${ }^{24}$ The most probable date of adoption of the lex Iulia maiestatis is 47 B.C. For more details, see M. Dyjakowska, Crimen laesae maiestatis..., pp. 32-33. 
A similar statement from the rescript of Antoninus Pius and Severus is referred to in the same title of the $9^{\text {th }}$ Book of the Code of Justinian:

C. 9.8.6.4: In hac causa in caput domini servi torquentur, id est propter causam maiestatis.

Interrogation with the use of torture was also used in the Granius Marcellus trial in A.D. 15 conducted before the Senate court. Marcellus was accused of a crimen maiestatis because he had allegedly insulted Augustus' statue. However, Suetonius' report did not make it clear whether it was the accused or his slaves who had been tortured.$^{25} \mathrm{~L}$. Schumacher, who holds that this is about the torture of slaves in caput domini, stressed that the hearing was not at the emperor's request, but at the initiative of the court which, in an attempt to fulfill Tiberius' presumed wish, violated procedural requirements. According to this author, this trial set an important precedent for the future use of queastio servorum in maiestas trials without the emperor's initiative. Therefore, when M. Scribonius Libo was brought before justice the next year, the torture against his slaves would have not been a legal problem if the basic charge had concerned lese-majesty. ${ }^{26}$

While during the reigns of Augustus and Tiberius the emperors resorted to the selling of slaves to be questioned in cases against their owners with the aim to comply with (at least formally) the principle of the inadmissibility of slave testimony in caput domini, this practice was replaced over time by taking the slaves from their owners for the benefit of the state only after the questioning. Ulpian explained that this was intended to induce slaves to tell the truth, since, on the one hand, they did not have to fear retaliation from the accused in case the testimony turned out to be unfavourable to them, on the other hand - they could not count on a reward from their owner, if they helped him by false testimony:

Ulp. D. 48.5.28.11 and 13: Iubet lex eos homines, de quibus quaestio ita habita est, publicos esse. ... ratio autem publicandorum servorum ea est, ut sine ullo metu verum dicant et ne, dum timeant se in reorum potestatem regressuros, obdurent in quaestione. 13. Sed et si negaverint, nihilo minus publicantur: ratio enim adhuc eadem est, ne, dum hi sperant se in potestatem dominorum reversuros si negaverint, spe meriti collocandi in mendacio perseverent.

Although the above explanation comes from Ulpian's work on adulteries, not lese-majesty, it seems that the information contained therein can be applied by analogy to the proceedings in cases of maiestas, since in both matters it was allowed to question slaves in caput domini. ${ }^{27}$

${ }^{25}$ Suet. Tib. 58: ... acta res in senatu et quia ambigebatur per tormenta quaesita est. Cf. Tacitus, Annales 1.74 .

${ }^{26}$ L. Schumacher, op. cit., pp. 126-130.

${ }^{27}$ U. Vincenti, op. cit., p. 87. 


\section{CRIMEN MAIESTATIS AS AN EXCEPTION FROM THE PROHIBITION OF ACCUSING THE OWNER BY A SLAVE}

The gravity of the crime of lese-majesty also determined the establishment of an exception to the rule prohibiting a slave from bringing an accusation against the owner:

Modest. D. 48.4.7.2: Servi quoque deferentes audiuntur et quidem dominos suos: et liberti patronos. ${ }^{28}$

This exception was not applied even at the time of Constantine, since - according to his constitution of A.D. 314 - the slave faced the penalty of death by crucifixion for accusing or denouncing the owner:

C.Th. 9.5.1.1: In servis quoque vel libertis, qui dominos aut patronos accusare aut deferre temptaverint, professio tam atrocis audaciae statim in admissi ipsius exordio per sententiam iudicis comprimatur ac denegata audientia patibulo adfigatur. proposita kal. ianuar. volusiano et anniano conss.

Although the constitution of A.D. 314 refers in general to accusing or denouncing the owner in the case of committing a crime, the fact that it is mentioned in the title Ad legem Iuliam maiestatis suggests that the crime of lese-majesty offence was not treated at that time as an act that would justify such a bold behaviour of a slave (tam atrox audacia). The fact that the constitution referred directly to the accusation of lese-majesty may be proved by the fact that in the Code of Theodosius it was preceded by a constitution of the same date providing for severe penalties to persons who recklessly accused others of this very crime (C.Th. 9.5.1 pr.). However, the legislation on this issue changed in subsequent years. Title 6 of Book 9 of the Code of Theodosius, bearing the symptomatic name Ne praeter crimen maiestatis servus dominum vel patronum libertus seu familiaris accuset, contains two very similar constitutions addressed to praetorian prefects, issued over a period of several years by various emperors:

C.Th. 9.6.2: ...quum accusatores servi dominis intonent, nemo iudiciorum exspectet eventum, nihil quaeri, nihil discuti placet, sed cum ipsis delationum libellis, cum omni scripturarum et meditati criminis apparatu nefandarum accusationum crementur auctores, excepto tamen appetitae maiestatis crimine, in quo etiam servis honesta proditio est: nam et hoc facinus tendit in dominos.

C.Th. 9.6.3: ... si quis ex familiaribus vel ex servis cuiuslibet domus cuiuscumque* criminis delator atque accusator emerserit, eius existimationem, caput atque fortunas petiturus, cuius familiaritati vel dominio inhaeserit, ante exhibitionem testium, ante examinatum iudicium, in ipsa expositione

${ }^{28}$ Slaves acting as accusers in trials of crimen maiestatis was treated as equal to women (Papin. D. 48.4.8), soldiers (Modest. D. 48.4.7.1) and infames (Modest. 48.4.7 pr.), i.e. those who had no right to accuse in other cases. 
criminum atque accusationis exordio ultore gladio feriatur. vocem enim funestam intercidi oportet potius quam audiri. maiestatis crimen excipimus.

Both constitutions concerned the prohibition of the acceptance of the accusation, or even denunciation submitted by a slave against the owner. According to the first of these constitutions, issued by Emperors Valens, Gracian and Valentinian in A.D. 376 , proceedings were not initiated on the basis of such accusations or reports, and the slave had to be punished with death by burning (along with the denunciation). More graciousness was demonstrated by the authors of the second constitution dating back to A.D. 397, Emperors Arcadius and Honorius, who stayed content with the death penalty by beheading. The only crime that a slave could accuse the owner without being afraid of death penalty was lese-majesty.

Legal sources do not answer the question whether the slave was also interrogated using torture in the case of accusation brought by a slave against his owner. It seems that this question should be answered negatively: the prospect of torture would certainly not encourage slaves to bring accusations, ${ }^{29}$ and yet the reason behind the extension of the group of those entitled to accuse of crimen maiestatis also to slaves was undoubtedly a concern for the most frequent disclosure of cases of planned or committed crime.

\section{CONCLUSION}

The special treatment of anti-state crimes in Roman law, including procedural peculiarities, was manifested in the admission of accusation made by those who were not granted such a right in other cases, and such persons were also slaves in respect of their owners. The gravity of this crime also determined the departure from the ban on interrogating slaves to the detriment of the owners. Thus, although there was a rule in Roman law that a slave could not aggravate the situation of his owner, ${ }^{30}$ in situations of a threat to public order, this rule was ignored.

29 P.A. Brunt, op. cit., p. 256.

${ }^{30}$ Gaius D. 50.17.133: Melior condicio nostra per servos fieri potest, deterior fieri non potest. E. Loska (op. cit., p. 463) notes that the essence of this rule concerned legal actions carried out by slaves, but it can also be referred to a situation where the testimony of a slave may have led to the conviction of his owner. 


\section{REFERENCES}

Bauman R.A., The Crimen Maiestatis in the Roman Republic and Augustan Principate, Johannesburg 1970.

Brunt R.A., Evidence given under Torture in the Principate, "ZSS" 1980, vol. 97(1), DOI: https://doi.org/10.7767/zrgra.1980.97.1.256.

Chmiel A., Immediacy Principle in Roman Criminal Procedure, „Krytyka Prawa” 2016, vol. 8(2).

Chmiel A., Ochrona bezpieczeństwa właścicieli niewolników w świetle S.C. Silanianum-zagadnienia dowodowe, [in:] Ochrona bezpieczeństwa i porządku publicznego w prawie rzymskim, eds. K. Amielańczyk, A. Dębiński, D. Słapek, Lublin 2010.

Chmiel A., Zasada kontradyktoryjności w rzymskim procesie karnym, „Zeszyty Naukowe Uniwersytetu Rzeszowskiego. Seria Prawnicza. Prawo" 2018, no. 101,

DOI: https://doi.org/10.15584/znurprawo.2018.22.3.

Dyjakowska, Crimen laesae maiestatis. Studium nad wplywami prawa rzymskiego w dawnej Polsce, Lublin 2010.

Dyjakowska, Ochrona bezpieczeństwa i porzadku publicznego a rzymskie ustawy o obrazie majestatu, [in:] Ochrona bezpieczeństwa i porzadku publicznego w prawie rzymskim, eds. K. Amielańczyk, A. Dębiński, D. Słapek, Lublin 2010.

Litewski W., Rzymski proces karny, Kraków 2003.

Loska E, Kilka uwag na temat zeznań niewolników w procesie karnym, „Zeszyty Naukowe KUL” 2017, no. 3 .

MacMullen R., Enemies of the Roman Order: Treason, Unrest, and Alienation in the Empire, Cambridge 1966.

Mommsen Th., Römisches Strafrecht, Graz 1955.

Pesch A., De perduellione, crimine maiestatis et memoria damnata, Aachen 1995.

Robinson O., Slaves and the Criminal Law, "ZSS” 1981, vol. 98(1),

DOI: https://doi.org/10.7767/zrgra.1981.98.1.213.

Rogers R.S., Criminal Trials and Criminal Legislation under Tiberius, Middletown 1935.

Russo-Ruggeri C., Quaestiones ex libero homine. La tortura degli uomini liberi nella repressione criminale romana dell'eta repubblicana e del I secolo dell'imperio, Milano 2002.

Schisas P.M., Offences Against the State in Roman Law and the Courts Which Were Competent to Take Cognisance of Them, London 1926.

Schumacher L., Servus index: Sklavenverhör und Sklavenanzeige im republikanischen und kaiserzeitlichen Rom, Wiesbaden 1982.

Seibt W., Die Majestätsprozesse vor dem Senatsgericht unter Tiberius, Wien 1969.

Sitek B., ,Q Questionem” intellegere debemus tormenta et corporis dolorem ad eruendam veritatem, [in:] Crimina et mores. Prawo karne i obyczaje w starożytnym Rzymie, ed. M. Kuryłowicz, Lublin 2001.

Solidoro Maruotti L., La disciplina del crimen maiestatis tra tardo antico e medioevo, [in:] Diritto e giustizia nel processo. Prospettive storiche constituzionali e comparatistiche, eds. C. Cascione, C. Masi Doria, Napoli 2002.

Triggiano A., Evidence Given under Torture in Aristotle and Cicero, "Teoria e Storia del Diritto Privato" 2009, no. 2.

Vincenti U., ,,Duo genera sunt testium”. Contributo allo studio della prova testimoniale nel processo romano, Padova 1989.

Zumpt A.W., Das Criminalrecht der römischen Republik, vol. 2, part 1, Aalen 1993. 
Pobrane z czasopisma Studia Iuridica Lublinensia http://studiaiuridica.umes.pl Data: 26/04/2023 08:46:48

\begin{abstract}
ABSTRAKT
Zgodnie z zasadą obowiązującą w republikańskim Rzymie nie można było wykorzystywać zeznań niewolników na szkodę ich właścicieli, w szczególności w sprawach zagrożonych karą śmierci (in caput domini), niewolnicy nie mogli także wnosić oskarżeń przeciwko właścicielom. Do niewielu przestępstw, w których dopuszczalne były wyjątki od tej zasady, należała zbrodnia obrazy majestatu. W niniejszym artykule zaprezentowano najważniejsze poglądy rzymskich autorów na wiarygodność zeznań złożonych na torturach, a także wyjaśniono powody stosowania tortur w przesłuchaniach niewolników. W okresie pryncypatu zakaz przesłuchiwania niewolników przeciwko właścicielom był obchodzony, a następnie został zniesiony przez konstytucje cesarskie. W okresie dominatu zbrodnia obrazy majestatu była jedyną, w której niewolnikowi wolno było złożyć oskarżenie przeciw właścicielowi.
\end{abstract}

Slowa kluczowe: przesłuchanie; okres pryncypatu; okres dominatu; niewolnik; zbrodnia obrazy majestatu 